\title{
Establishment and Management of Mutual aid Learning Platform for University Students Based on Internet Plus
}

\author{
Xiaoqian Lu' ${ }^{1}$, Xiaofeng Chen ${ }^{1}$, Yanjing $\mathrm{Li}^{2}$, Yan Sheng ${ }^{3}$, Zejiong Zhou ${ }^{4}$, * \\ ${ }^{1}$ School of Finance, Anhui University of Finance and Economics, Bengbu, China \\ ${ }^{2}$ School of Accounting, Anhui University of Finance and Economics, Bengbu, China \\ ${ }^{3}$ School of Finance and Public administration, Anhui University of Finance and Economics, Bengbu, China \\ ${ }^{4}$ School of Economics, Anhui University of Finance and Economics, Bengbu, China \\ *Corresponding author: Zejiong Zhou (Email: aczzj123456@163.com)
}

\begin{abstract}
In light of the advantages and disadvantages of various learning support platforms in universities and the needs of students in schools, we have launched a learning platform based on Internet plus. This is an APP for college students. Firstly, this paper introduces the products, services and business model of the learning platform. Secondly, PEST method and SWOT method are used to analyze the market competition of the learning platform. Thirdly, it analyzes the marketing strategy and financial situation of the learning platform. Finally, it analyzes the risks faced by the learning platform and preventive measures.
\end{abstract}

Keywords: Learning platform, Business model, Market competition, Financial analysis.

\section{Introduction}

Under the influence of the network and digital and networked new media, the rapid development of educational informatization and the traditional teaching and learning mode of universities have been greatly affected and impacted. Mobile Internet technology and products have become one of the important tools for students' learning. Students can use mobile learning terminals to obtain the required learning resources to the greatest extent in any place and at any time, rich network learning resources are of great help to students' learning. The learning attitude, learning methods, learning approaches and learning objectives of college students have been changed, and the learning environment is no longer limited to offline classrooms and classrooms, which means that students have more self selection opportunities to choose their own learning environment, which is no longer limited by geographical restrictions and knowledge acquisition channels [1]. The $\mathrm{O} 2 \mathrm{O}$ mode of "Internet plus" provides more quality educational resources and educational opportunities for the students to get in touch with the knowledge they need. $\mathrm{O} 2 \mathrm{O}$ education mode is a new education mode that combines traditional classroom teaching with modern online technology.

Problems in college students' learning: on the one hand, college classroom teaching has large capacity and many knowledge points, making learning more difficult. On the other hand, college students' learning motivation is insufficient, their self-discipline decreases, and they let go when they encounter problems that are not solved in time or can not be solved, resulting in more and more problems and greater difficulty in learning, which eventually leads to weariness and abandonment of learning, which has a great impact on subsequent learning [2]. It is a method to find and put forward problems in the process of students' autonomous learning, and solve problems through the guidance and help of students with excellent character and learning, so as to improve academic performance and learning efficiency and stimulate learning motivation.

Nowadays, many universities have various learning exchange groups, official account or website. Their original intention is to solve the problems that students encounter in school or life. However, some schools have several learning and communication platforms, which easily lead to students joining multiple groups and paying attention to multiple official account numbers. Eventually, all kinds of information are dispersed, and the information is not timely or missed. Although the learning exchange group can enhance the communication between students, there are many students chatting in the group, which reduces the learning atmosphere, and a large number of difficult problems raised by students are brushed away by chat records. Various notices in the group are not timely and the data classification is messy. The official account can share some learning experience and inform relevant information in time, but this greatly reduces the problem communication and answer questions between [3]. In addition, due to a mutually independent state among various schools, it is difficult to share excellent materials and resources, which hinders the learning exchange and data exchange of students from different schools.

Combined with the advantages and disadvantages of various learning and mutual aid platforms in universities, and through the investigation and analysis of the needs of students, we have launched a learning platform based on Internet plus. This is an app for college students. This platform can provide clearer, faster and more targeted information for college students. To a certain extent, it can meet some learning and life needs of students, and expand the types of services provided. Using Internet technology, e-commerce technology and other technologies, facing the majority of teachers and students, schools and associations, through the combination of online and offline, students with spare power can help other students and promote the communication between students and students, students and teachers. Provide a learning exchange and mutual assistance platform for college students across the country [4].

\section{Products and Services}

\subsection{Overview of Main Products and Services}

"Xuexin" is a product that insists on providing the most high-quality and comprehensive service for college students. 
It aims to help college students understand the basic information of the school at the beginning of entering the school, provide information on learning, examination and competition, and take centralized and targeted measures by using the e-commerce platform. The main business of this platform: understand the information of the school and use the relevant websites and applets of the school; Introduce relevant certificates, competitions and experiences to students in learning, so that freshmen can have a correct plan for their freshman study and life when they enter the school; Answer the difficult questions for the students in the course at ordinary times.

The original intention of the "Xuexin" platform is to solve the problems of scattered University materials and information, many students' problems can not be well solved, unable to understand or miss some competition and textual research information, that is, an app for learning and life mutual assistance among college students.

\subsection{Introduction to Main Services and Functions}

\subsection{1. . Data Information}

(1) School information. School profile, such as school calendar, school map, express address, dormitory allocation rules, canteen introduction, community introduction, introduction to food, drink and play near the school, mainly including pictures, words and videos; The use methods of school network platform take Anhui University of Finance and Economics as an example, such as online library, credit scanning, the use tutorials of Anhui University of Finance and Economics E-PASS and school apartment pass, etc.

(2) Exam competition. Examination competition services are as follows: introduction to school subject examination. General introduction of the certificate, recommended preparation time and counseling. Competition content and function introduction, etc.

(3) Other learning materials. Other learning materials mainly include course notes, test questions, pictures and PPT templates.
(4) Data area. Classify and sell the materials of schoolsisters, seniors or teachers according to categories. For example, the sale of second-hand information books.

\subsubsection{Online Help}

(1) Learn difficult questions and answer questions. You can take photos and upload them to the community. "Q\&A post": the user puts forward the questions to be solved in the relevant interface position, which can be answered by other users and our Q\&A sister and senior students, and members can view the high-quality answers. Ordinary users can publish up to 2 Q\&A posts a day, and member users can publish up to $5 \mathrm{Q} \& \mathrm{~A}$ posts a day, and the Q\&A posts of member users will be preferentially pushed to our sister and senior students in charge of Q\&A. Member users can ask questions about the answers to the Q\&A Posts sent by themselves or others.

(2) Invite team function. The team leader releases the team formation post of competition or social practice (write down the skill requirements and grade requirements for the team members), and then other users can click to apply to join and write the self introduction of each search requirement set by the initiator. The team poster selects the final candidate, and then you can turn on the chat function.

(3) Help fill in the questionnaire. Member users can publish the questionnaire links to be filled in on the platform, and set the range of filling personnel (such as a school or a school in a region) to help other users fill in; In order to encourage other users to help fill in, we have launched the following incentive methods: users who fill in five questionnaires can get a published questionnaire or view a high-quality answer to a difficult post, and students who fill in ten questionnaires can get a three-day membership experience.

\section{Business Model}

\subsection{Profit Model}

\subsubsection{Membership Fee}

User members will be charged according to the following table:

Table 1. Member price list

\begin{tabular}{|c|c|c|c|}
\hline & $\begin{array}{c}\text { Recharge during } \\
\text { free operation }\end{array}$ & $\begin{array}{c}\text { Recharge after free operation } \\
\text { in the early stage }\end{array}$ & $\begin{array}{c}\text { Recharge in the middle and later } \\
\text { stage of operation }\end{array}$ \\
\hline $\begin{array}{c}\text { Monthly charge (excluding June } \\
\text { and December) }\end{array}$ & 6 yuan / month & 7 yuan / month & The original price is about +-5 \\
\hline $\begin{array}{c}\text { Recharge monthly in June and } \\
\text { December of the examination } \\
\text { month }\end{array}$ & 9 yuan / month & $12 /$ month & The original price is about +-5 \\
\hline Quarterly charge & 15 yuan / quarter & 19 yuan / quarter & The original price is about +-5 \\
\hline One year charge & 58 yuan / year & 74 yuan / year & The original price is about +-5 \\
\hline
\end{tabular}

Note: (1) there is no charge for the first half year of operation (one-on-one counseling for seniors and sisters is not included); (2) The member only aims at the Q\&A post function, inquiry function, page beautification function and some additional functions; (3) Member users enjoy more privileges: for difficult questions, you can view high-quality answers and follow-up functions. Member users can publish two more Q\&A posts a day than ordinary users, and the Q\&A posts of member users will be preferentially pushed to our senior students in charge of Q\&A.

\subsubsection{Advertising Expenses}

Generally, it is a profit-making model in the middle and later stages. After the platform is mature and has sufficient user groups, the platform will attract various counseling institutions in the society to charge advertising fees and franchise fees.

\subsection{Sales Model}

(1) Free marketing. Free marketing refers to providing consumers with products or services reflecting user value at low or zero price, and obtaining income through other 
channels. Free is a sharp weapon to quickly hit the consumer market. There is no charge for the basic functions of the platform in the first half of the year. In order to attract consumers to use and convert paying users, Xuexin provides learning resources, certificate introduction, etc., and subdivides the content into different modules, covering all aspects of learning, life and work, meeting the needs of different groups.

(2) One to many marketing. One to many marketing evolved from one-to-one marketing. One to one is the docking of independent customers, and one to many is the docking of customer groups. This marketing method creates personalized marketing communication for each customer group. The key point is to classify customers and establish interactive and personalized business processes. A customer group carries out sales promotion or marketing to introduce, display and promote the performance and characteristics of a product or service to a group of buyers with the same needs, so as to promote their purchase. Students launch different products for students of different grades and students with different needs.

(3) Social media marketing. With the in-depth development of the Internet and the wide use of social media, more and more platforms strive to occupy a place through social media. Taking advantage of the situation, students have launched a punch in cash and punch in incentive mechanism to pay tuition fees and enjoy the course and online head teacher supervision services. After the course meets the standard, part of the tuition fees will be returned or other gifts will be rewarded. But users also have to pay a "price" - punch in the circle of friends. When the number of punch outs forms a certain scale, most consumers will also choose to join this group to avoid group sanctions due to isolation.

\section{Market and Competition Analysis}

\subsection{Macro Environment Analysis - PEST Analysis}

\subsubsection{Political Environment}

(1) National support policies on innovation and entrepreneurship. (1)Encourage local governments to set up venture funds and give preferential treatment to the office space and network of maker space. Tax support will be given to small and micro enterprises, incubators and angel investments in innovation activities. The pilot of individual income tax payment by installments of share capital and equity incentives for science and technology enterprises will be promoted to the whole country. (2) Through innovative financing methods such as investment loan linkage and equity crowdfunding, we will promote the listing of start-ups with special equity structure in China and encourage the development of mutual insurance. Give play to the seed fund role of national venture capital guidance funds, and support state-owned capital and foreign capital to carry out venture capital business. (3) Abolish restrictions on registered residence and academic qualifications that impede the free flow of talents, and create conditions for facilitating entrepreneurship and innovation. Leave room for the growth of new technologies, new business formats and new models, and do not set up cards at will. (4) Revitalize idle plants, logistics facilities, etc., and provide low-cost office space for entrepreneurs. Develop business incubation and third-party services such as marketing and finance. (5) Streamline administration and delegate power, combine decentralization and management, optimize services, and give better play to the role of the government, so as to stimulate market vitality and promote "mass entrepreneurship and innovation". Strengthen the protection of intellectual property rights and add strength to entrepreneurship and innovation by building information, technology and other sharing platforms and government procurement.

(2) Special preferential policies for college students. (1) Tax preference. If college graduates who hold the employment and entrepreneurship certificate issued by the human resources and social security department (note "tax policy for independent entrepreneurship within the graduation year") establish individual industrial and commercial households and sole proprietorship enterprises within the graduation year (referring to the natural year where they graduate, i.e. January 1 to December 31 ), their actual business tax, urban maintenance and construction tax Education surcharge and individual income tax. Small low profit enterprises founded by college graduates shall enjoy relevant tax support policies according to national regulations (2)Entrepreneurship guaranteed loans and interest discounts. For qualified college students who start their own businesses, they can apply for entrepreneurship guarantee loans in the place of entrepreneurship according to regulations, with a loan amount of 100000 yuan. Financial institutions are encouraged to reasonably determine the loan interest rate level with reference to the basic loan interest rate and in combination with the risk sharing situation. For the entrepreneurship guarantee loan issued by individuals, if it rises by less than 3 percentage points on the basis of the basic loan interest rate, the finance shall give a discount. (3) Relevant administrative fees shall be exempted. Ordinary college students who have graduated within 2 years and are engaged in self-employed business (except industries restricted by the state) are exempted from administrative fees, registration fees, licenses and other relevant administrative fees within 3 years from the date of their first registration with the industrial and commercial department. (4)Enjoy training subsidies. For small and micro enterprises founded by college students who newly recruit college graduates of the year of graduation, sign labor contracts for more than one year and pay social insurance premiums, they will be given social insurance subsidies for one year. For college students who participate in entrepreneurship training in the graduation school year (i.e. 12 months from July 1 of the year before graduation), training subsidies shall be given according to the qualification certificate of entrepreneurship training or employment and entrepreneurship. (5)Free entrepreneurship services. College students with entrepreneurial intention can obtain the entrepreneurial guidance services provided by public employment and talent service institutions free of charge, including "one-stop" entrepreneurial services such as policy consultation, information services, project development, risk assessment, business guidance, financing services and tracking support. (6) Cancel the restrictions on the settlement of college graduates. College graduates can go through the settlement procedures in the place of Entrepreneurship (municipalities directly under the central government shall implement the relevant provisions). (7)The policy supports the "first violation exemption" of College Students' entrepreneurship. The departments of industry and commerce, urban management and law enforcement only give warnings and warnings to college graduates for the first 
time in the process of entrepreneurship, which are minor and do not cause harmful consequences to society and others, and help college students entrepreneurs correct them without administrative punishment.

\subsubsection{Economic Environment}

According to the latest online education industry insight report released by questmobile, a mobile Internet big data company, the number of monthly active users of education apps has exceeded 220 million. In April 2018, the total downloads of education and training app in the app store increased by $72.8 \%$ year-on-year, exceeding 250 million times, equivalent to $4.5 \%$ of the whole network app downloads. Another trend covering the whole field of education is the rise of users in third and fourth tier cities. Different from other categories, the proportion of users in first tier cities in educational apps is only 13\%. Questmobile's report believes that due to the rapid popularization of mobile terminals, online education solves the space problem that traditional education is difficult to cross and the problem of teacher coverage to a certain extent.

According to the Research Report on the development of China's educational app industry and user industry jointly released by Sina education and Nielsen research company, the total number of educational applications in China has exceeded 70000 , accounting for about $10 \%$ of the app market share, ranking second only to games. According to statistics, more than $70 \%$ of users have used the education app within half a year, of which $85.8 \%$ of existing users express their willingness to continue to use it in the future, and $56 \%$ of users are willing to pay for the education APP.

\subsubsection{Social Environment}

In the target customer group of campus e-commerce college students, most students have common interests, needs and consumption tendencies. Consumer goods are single compared with social groups, which provides a more consistent customer group for campus e-commerce. In terms of quantity, according to the data of China National Bureau of statistics, the number of ordinary undergraduate students has been increasing year by year in recent ten years, and the target user group is large and has a continuous increasing trend.

Due to the exposure of individual academic misconduct events, the quality of undergraduate education has attracted more and more attention and supervision from all walks of life. In addition, with the change of school training program, the high requirements for students' academic ability, the strong exercise of students' scientific research level, participating in discipline competitions, publishing papers, carrying out social practice and solving every problem in the learning process, the needs of these college students are becoming more and more concentrated.

Table 2. SWOT matrix comprehensive analysis

\begin{tabular}{|c|c|c|}
\hline & Advantage (S) & Disadvantages (W) \\
\hline Internal conditions & $\begin{array}{l}\text { 1. The professional learning contents, } \\
\text { competitions and other materials in the } \\
\text { school are highly professional and } \\
\text { targeted. } \\
\text { 2. Easy to operate and spread. } \\
\text { 3. Meet the needs of college students at all } \\
\text { stages and have a high degree of } \\
\text { acceptance. } \\
\text { 4. Complete data integration to solve the } \\
\text { problem of information dispersion. } \\
\text { 5. It is created by students in the school } \\
\text { with high credibility. }\end{array}$ & $\begin{array}{l}\text { 1. As a newcomer to the market, he lacks } \\
\text { mature industry operation and marketing } \\
\text { experience. } \\
\text { 2. Lack of market awareness and rapid } \\
\text { technical improvement ability. } \\
\text { 3. There is still much room for improvement } \\
\text { in the model. } \\
\text { 4. It is difficult to expand and promote users. } \\
\text { 5. Impact of the existing campus platform. } \\
\text { 6. It is difficult to complete the signing of } \\
\text { customer integration and explanation teachers } \\
\text { at the initial stage. }\end{array}$ \\
\hline & SO strategy & OW strategy \\
\hline $\begin{array}{l}\text { 1. The state has always } \\
\text { had a positive attitude of } \\
\text { support for college } \\
\text { students' innovation and } \\
\text { entrepreneurship. } \\
\text { 2. Smart phones and } \\
\text { student groups have a } \\
\text { high acceptance of the } \\
\text { network. }\end{array}$ & $\begin{array}{l}\text { 1. Give full play to the advantages of } \\
\text { content and expand the number of users on } \\
\text { the basis of feasible technology and use. } \\
\text { 2. Cooperate with relevant departments to } \\
\text { make full use of preferential policies for } \\
\text { innovation and entrepreneurship. }\end{array}$ & $\begin{array}{l}\text { 1. Introduce technicians. } \\
\text { 2. Strengthen publicity and promotion to } \\
\text { realize the convenience and compatibility of } \\
\text { the platform. } \\
\text { 3. Pay attention to user problem feedback and } \\
\text { improve reputation. }\end{array}$ \\
\hline Challenge & ST s & WT \\
\hline $\begin{array}{l}\text { 1. Hit by existing } \\
\text { companies in the } \\
\text { industry. } \\
\text { 2. The purchase and } \\
\text { production of materials } \\
\text { involve copyright issues. }\end{array}$ & $\begin{array}{l}\text { 1. Strengthen technological upgrading. } \\
\text { 2. Strengthen publicity and promote } \\
\text { according to demand. } \\
\text { 3. Make and establish its own copyright } \\
\text { material system as soon as possible. }\end{array}$ & $\begin{array}{l}\text { 1. Design and manufacture directly combined } \\
\text { with the latest technology to turn weakness } \\
\text { into advantage and reduce product upgrading } \\
\text { cost. } \\
\text { 2. Improve the comprehensive content system } \\
\text { to meet the demand under the requirements of } \\
\text { data content and quantity. }\end{array}$ \\
\hline
\end{tabular}

\subsubsection{Technical Environment}

In the construction of university campus, network equipment is more important than application system. The application system of campus e-commerce information system is seriously lacking. Now the so-called "campus network" in the market are mostly equipment solutions proposed by some manufacturers based on advanced hardware, and there is no perfect application system. The 
application based on campus network is generally limited to meeting the necessary functions of campus card recharge, balance query, classroom borrowing, electricity payment and so on. There is an obvious gap in the development and application of innovative functions. With $5 \mathrm{~g}$ paving the way for AR / VR experience, campus e-commerce can apply these technologies to a variety of new educational technologies. Compared with traditional education methods, AR / VR education platform provides many benefits, including costeffectiveness and risk reduction. Due to the low throughput, high latency and inconsistent connectivity of mobile devices, the functions and characteristics of cloud computing are often diluted. However, 5G network can improve influence and flexibility. 5G's high throughput and low latency will be able to solve existing problems, promote cloud computing to another level, and continue to pave the way for big data analysis. Increasing interactive experience and faster network transmission speed further promote the upgrading of smart phones, and the production cost is gradually reduced in the change of technology. Nowadays, the penetration and utilization rate of intelligent mobile terminals in university campuses is self-evident saturation. There are almost no technical problems in the development and application of campus e-commerce [5].

\subsection{SWOT Analysis}

SWOT analysis method is an enterprise strategic analysis method, that is, according to the established internal conditions of the enterprise, to find out the advantages, disadvantages and core competitiveness of the enterprise. Analyze the opportunities, threats, strengths and weaknesses formed by the internal and external environment of the organization, so as to find a method to formulate business strategies and strategies suitable for the actual situation of the organization. Among them, S and $\mathrm{W}$ are internal factors, and $\mathrm{O}$ and $\mathrm{T}$ are external factors. Clearly determining the resource advantages and disadvantages of the project and understanding the opportunities and challenges faced by promotion and marketing are of great significance to formulate the future development strategy of the project.

\section{Marketing}

The company formulates different marketing strategies for different stages, and gives examples to illustrate the reasons for the implementation of the strategy. In the early stage, the promotion scope is mainly in Colleges and universities in the province. Online one-to-one chat promotion is mainly used, together with offline field publicity. Such promotion may consume more human and material resources, but the effect is considerable. It can expand the user group in a short time and obtain a better group foundation for further promotion in the future. In the middle and later period, after having a certain reputation, we should further expand the popularity by contacting the official account and holding large events. Based on the basis of colleges and universities in the province, follow the previous promotion strategy to further promote to colleges and universities outside the province, and develop into a well-known domestic college student learning software.

\subsection{Marketing Strategy}

\subsubsection{Early Promotion}

The promotion scope is concentrated in Colleges and universities in the province, mainly by online withdrawal and supplemented by offline activities.
Online publicity. (1) cooperate with the existing learning groups in the school. By paying a certain promotion fee, we can get the opportunity to promote regularly in the learning group. The learning group of a school often gathers the students who actively study in the school. At the same time, it also contains a large number of learning materials. While promoting, it can also improve the software database and kill two birds with one stone. If it is difficult to cooperate, you can also choose other group chat in Colleges and universities. In short, you should make good use of group resources. (2) Chat tool promotion. We can build our own QQ group or find an agent in the school to talk and promote one by one through chat software, so as to facilitate interested people to further understand. This is one of the main ways of online basic promotion, and it is also a more effective means of promotion when the software starts. (3) E-mail Promotion. That is, extensive mass software promotion information is a timesaving and labor-saving large-area promotion form.

Offline publicity. (1) Cooperate and promote with learning associations in Colleges and universities. For example, when recruiting new students, this is because freshmen are easier to accept promotion than old students, and freshmen are the main target customer group of our software. Holding promotion lectures can cooperate with the basic credit awards of some colleges and universities to attract students' participation. (2) Conduct field publicity in Colleges and universities. For example, holding activities in canteens and other places with large flow, supplemented by registration, sending small gifts, sending publicity points to the circle of friends, and cashing awards with full praise; It also includes on-site distribution of leaflets, door-to-door publicity in teaching buildings and dormitory buildings, which is the main way of offline basic promotion in the early stage.

\subsubsection{Promotion in the Middle and Later Stages}

The promotion activities will be expanded outside the province, and further publicity will be carried out online and offline.

Online promotion. (1) To have a basic user with a certain amount of cooperation, seeking cooperation with the official account of universities, and pushing the learning and professional news of software updates. (2) After having a certain economic strength, carry out advertising on the website pages with more views. (3) The software can give warm feedback to existing users, such as issuing coupons and receiving materials for free, so as to consolidate users.

Offline promotion. (1) Cooperate with college teachers, such as teachers uploading learning materials to the software, in order to fix the existing user group through authority. (2) Sponsor large-scale learning competitions to further enhance the popularity of software through such large-scale activities.

\subsection{Marketing Strategy}

\subsubsection{Product Strategy}

Continuously optimize the product content and improve various functions of the product, such as updating the database in real time, ensuring the timeliness and integrity of learning materials, and giving professional teacher certification to key materials to ensure their authority; For professional difficulties, supporting explanation videos. Improve the timely prediction and feedback of various competitions, and strengthen the construction of relevant platforms.

\subsubsection{Price Strategy}

For the pricing of users, the early stage of software 
promotion mainly focuses on the free trial of various functions. After the trial period, the membership system is implemented, and members are free to open the database and discount some functions. In addition, the software will issue coupons and free materials from time to time to give back to inherent users. Exclusive benefits will be granted to participants who can provide high-quality information and detailed video [6].

\subsubsection{Channel Strategy}

Throughout the promotion process, the online and offline dual channel promotion strategy runs through, and online publicity and offline activities are carried out based on the methods available at each stage, so as to expand the popularity and user base in a short time as far as possible.

\subsubsection{Promotion Strategy}

Use the learning process to carry out targeted promotion, such as issuing material coupons at the middle and end of the semester, providing half price sprint courses, online boutique counseling, etc. Provide guidance on social practice from team formation to topic selection before the holiday. Organize a comprehensive entrance guide for freshmen before school starts.

\section{Financial Analysis}

\subsection{Financing Plan and Fund Use}

\subsection{1. . Financing Scheme}

Financing limit: 80000 yuan.

Table 3. Sources of funds

\begin{tabular}{|c|c|c|c|}
\hline Fund composition & Internal financing & \multicolumn{2}{|c|}{ External financing } \\
\hline Source of funds & Raise independently & Venture loans & Equity financing \\
\hline Amount (10000 yuan) & 3 & 3 & 2 \\
\hline Proportion & $37.5 \%$ & $37.5 \%$ & $25 \%$ \\
\hline
\end{tabular}

Notes: (a) venture loan of 50000 yuan refers to the application for Bengbu college students' venture loan. (b) The above funds are used for the initial establishment of enterprises and market development.

\subsubsection{Purpose of Funds}

The purpose of the fund is as follows: sales promotion and service fees required to develop the market; Operation management of online platform and related employee compensation; Rental of premises and purchase of relevant office supplies. Development and future improvement of software platform. Purchase a certain amount of learning materials and test papers. Used for working capital to deal with unexpected situations.

\subsection{Financial Analysis}

The share capital structure and scale are as follows:

Table 4. Equity structure and model

\begin{tabular}{|c|c|c|c|}
\hline $\begin{array}{c}\text { Share capital ratio / share capital } \\
\text { structure }\end{array}$ & $\begin{array}{c}\text { The fund of the founding } \\
\text { team is invested }\end{array}$ & $\begin{array}{c}\text { Attract venture capital to take } \\
\text { shares, }\end{array}$ & $\begin{array}{c}\text { Venture capital } \\
\text { investment }\end{array}$ \\
\hline Amount of money & 30000 yuan & 20000 yuan & 30000 yuan \\
\hline Proportion & $37.5 \%$ & $25 \%$ & $37.5 \%$ \\
\hline
\end{tabular}

The fund sources of APP construction are mainly self raised funds and loan financing by team members, and the equity scale is distributed according to the main contribution proportion.

Table 5. Income statement

\begin{tabular}{|c|c|c|c|}
\hline Project & First year & Second year & Third year \\
\hline 1.Operating income & 15000 & 20000 & 35000 \\
\hline Less: operating costs & 6250 & 4100 & 5200 \\
\hline Business tax and surcharges & 860 & 920 & 1300 \\
\hline Financial expenses & 480 & 480 & 480 \\
\hline Sales and administrative expenses & 2810 & 2930 & 3510 \\
\hline 2. Operating profit & 4600 & 0 & 24510 \\
\hline Plus: non operating income & 0 & 0 & 0 \\
\hline Non operating expenses & 0 & 11570 & 0 \\
\hline 3. Total profit & 4600 & 2314 & 24510 \\
\hline Less: income tax & 920 & 9254 & 4902 \\
\hline 4.Net profit & 3680 & & 19608 \\
\hline
\end{tabular}

Note: (1) operating profit = operating income - operating cost - business taxes and surcharges - financial expenses sales management expenses net profit $=$ operating profit + non operating income - non operating expenses - income tax. (2) It is assumed that there is no non operating income and non operating expenditure. (3) Income tax is levied at $20 \%$ of the total profits. (4) As it is an entrepreneurial project, the salary of personnel will not be considered temporarily.
It can be seen from the data in the table that the profit in the early stage of software operation is meager, mainly focusing on promotion. When it begins to take shape, the profit increases linearly and the profitability of software is strong.

The above table is the asset estimation of the enterprise in the next three years after certain investigation and calculation, which can reflect the following points:

(1) The capital scale of the enterprise is small, but the 
monetary capital accounts for a large proportion, the asset structure is reasonable, and the controllable economic resources of the enterprise are sufficient. (2) Although the enterprise has certain liabilities, its capital liquidity and liquidity are strong, and its short-term solvency is good. (3) The owner's equity accounts for a large proportion of the total liabilities and owner's equity and shows an increasing trend.
The enterprise has a strong ability to pay off long-term debts, and there is great potential for further debt initiatives. (4) Enterprises have less short-term liabilities, relatively more long-term liabilities and a decreasing trend. The enterprise needs to be cautious in its early operation and can expand its business in the later stage.

Table 6. Balance sheet

\begin{tabular}{|c|c|c|c|c|c|c|c|}
\hline Assets & $\begin{array}{l}\text { First } \\
\text { year }\end{array}$ & $\begin{array}{l}\text { Second } \\
\text { year }\end{array}$ & $\begin{array}{l}\text { Third } \\
\text { year }\end{array}$ & $\begin{array}{c}\text { Liabilities and } \\
\text { equity }\end{array}$ & First year & $\begin{array}{c}\text { Second } \\
\text { year }\end{array}$ & $\begin{array}{l}\text { Third } \\
\text { year }\end{array}$ \\
\hline Current assets & & & & Current liabilities: & & & \\
\hline Monetary Fund & 28,680 & 37,934 & 57,542 & Accounts payable & 10,000 & 5,000 & 3,400 \\
\hline Accounts receivable & 0 & 300 & 1,000 & Short term loan & 1,200 & 780 & 835 \\
\hline $\begin{array}{l}\text { Less: provision for bad } \\
\text { debts }\end{array}$ & 0 & 0 & 500 & Wages payable & 2,810 & 2,930 & 3,510 \\
\hline $\begin{array}{l}\text { Net accounts } \\
\text { receivable }\end{array}$ & 0 & 300 & 500 & Tax payable & 1,780 & 3,234 & 6,202 \\
\hline Total current assets & 28,680 & 38,234 & 58,042 & Total liabilities & 15,790 & 11,944 & 14,547 \\
\hline \multicolumn{8}{|l|}{ Fixed assets } \\
\hline $\begin{array}{l}\text { Original price of fixed } \\
\text { assets }\end{array}$ & 0 & 0 & 0 & Owner's equity: & & & \\
\hline $\begin{array}{l}\text { Less: accumulated } \\
\text { depreciation }\end{array}$ & 0 & 0 & 0 & Paid in capital & 10,000 & 10,000 & 15,000 \\
\hline $\begin{array}{c}\text { Net value of fixed } \\
\text { assets }\end{array}$ & 0 & 0 & 0 & Surplus reserve & 368 & 925.4 & 1960.8 \\
\hline Intangible assets: & 5,000 & 5,000 & 5,000 & Undistributed profit & $7,355.3$ & 21,331 & 31,234 \\
\hline $\begin{array}{l}\text { Less: accumulated } \\
\text { amortization }\end{array}$ & 1666.7 & 3333.4 & 50,000 & $\begin{array}{l}\text { Less: returned } \\
\text { investment }\end{array}$ & 1,500 & 4,300 & 4,700 \\
\hline $\begin{array}{l}\text { Net value of intangible } \\
\text { assets }\end{array}$ & $3,333.3$ & $1,666.6$ & 0 & $\begin{array}{l}\text { Total owner's } \\
\text { equity }\end{array}$ & 16,223 & 27,956 & 43,495 \\
\hline Total Assets & 32,013 & $39,900.6$ & 58,042 & $\begin{array}{c}\text { Total liabilities and } \\
\text { equity }\end{array}$ & 32,013 & 39,900 & 58,042 \\
\hline
\end{tabular}

\section{Risk and Prevention}

Although the development of campus exclusive education products is not a high-tech enterprise, it also has high business risk, production risk, market risk, talent risk and financial risk. In the face of risks, the company has formulated a comprehensive risk management mechanism to minimize the losses suffered by the company in the face of internal uncertainty, so as to maintain the stable operation of the company and ensure that investors obtain satisfactory returns. During the operation of the company, the main possible risks are: systematic risk and non systematic risk. System risk refers to the risk factors beyond the control of the enterprise itself, mainly refers to the risk factors in the environment faced by the enterprise, mainly including market risk, policy risk and natural risk. For system risk, the company needs to control the risk through avoidance. Non systematic risk refers to the risk factors that an enterprise can control to a certain extent, mainly including production risk, financial risk, management risk, etc. In the face of non systematic risks, the company sets up a risk prevention mechanism to control or resolve them. In addition, the risks faced by the company in each stage from establishment, operation to development and growth are different,

Although various risks appear in all stages of the company's growth, the primary and secondary levels are obviously different. In the initial stage of establishment, the company needs to use the production mode of independent research and development. At the same time, it needs to explore the market, which also needs financial support.
Therefore, it is mainly faced with production risk, market risk and capital risk. In the growth stage, the company has entered small batch production and needs to explore a larger market and expand production capacity. The risks it faces are mainly market risks and management risks. In the final stable period of expansion, the main risk is management risk.

\subsection{System Risk}

\subsubsection{Market Risks and Countermeasures}

College student mutual aid app belongs to learning and education products. Although the product is widely used, this product also has its own defects. Secondly, the competition of educational products is fierce, the phenomenon of homogenization is serious, and a large number of apps are eliminated in the competition.

Countermeasures or measures: in view of the above risks, we apply the remedy to the case. First, for the competition of various sales channels, we should highlight that our products are the exclusive learning and mutual assistance platform of colleges and universities, take the school as the unit and integrate into the campus culture. Moreover, the service provided by the platform is tailored to the college environment, solve the difficulties faced by many college students, brighten the eyes of consumers and add points to the platform. And through the app of this platform, we can cooperate with colleges and universities to increase publicity and shape the corporate image. Secondly, the company should correctly grasp the market demand, clarify the product positioning and target customer groups, so as to formulate the correct marketing strategy. The company should pay attention 
to brand building, strengthen the construction of marketing team, cultivate a marketing team who is familiar with both products and market, and strengthen customer service [7].

\subsubsection{Policy Risks and Countermeasures}

All along, the state has vigorously promoted the development of education, the enrollment of colleges and universities around the country has been increasing, and internal reforms have been implemented to promote development. The innovation of educational methods and ideas and the emergence of new things provide students with a variety of channels.

Countermeasures or measures: the company will strengthen the research on macroeconomic policies and market trends, make use of policy advantages, avoid policy disadvantages, and reasonably determine the company's development objectives and strategies. At the same time, the company will strengthen the contact and cooperation with government departments and university education departments to ensure timely understanding of the changes in confidence in relevant industries, so as to make decisions quickly, so as to enhance the ability of enterprises to resist policy risks.

\subsubsection{Natural Risks and Countermeasures}

The company is faced with various natural disasters. Although it is unlikely, once they occur, they will have a huge blow to the enterprise. Countermeasures or measures: insure the enterprise to minimize the loss of the enterprise

\subsection{Non Systematic Risk}

\subsubsection{Financial Risks and Countermeasures}

Financial risks exist in all links of financial work. Mistakes in any link may bring financial risks to the enterprise. In the process of our production and operation, the financial risks we face are mainly reflected in: financing safety, mainly the problems of capital debt in the process of financing, endangering the solvency, etc; The investment is safe, mainly because it does not lose money, and can make profits as expected and recover the investment on schedule; Expansion security is mainly the problem of capital shortage and investment failure in the process of expansion.

Countermeasures or measures: the company will improve the company's income and achieve the expected high rate of return through scientific project feasibility analysis and market-oriented marketing strategy. In addition, the company will strengthen financial management, make fund application planning, reduce financial expenses and idle cash, so as to improve the rate of return on net assets, so as to enable the company to take the lead in the financing process. At the same time, on the premise of ensuring the funds required for the normal operation of the company, try to raise the free funds of the enterprise, so that our idle funds can be used effectively.

\subsubsection{Business Risks and Countermeasures}

The company operates campus learning and life mutual aid products, which will be applicable to the school emblem and other signs of colleges and universities, involving the risk of infringement complaints about the use of university signs.

Countermeasures or measures: establish cooperative relations with colleges and universities and sign agreements to obtain the right to use the symbols of colleges and universities. The company promises to use the symbols such as the school emblem only for commercial purposes.

\subsubsection{Technical risks and Countermeasures}

Website construction is a large-scale development project, which involves the front-end and back-end development of the website, as well as the workflow of the whole website. The online time of the project cannot be changed, so the project progress is a risk of signing. The development of the website mainly uses JavaScript as the structural system of the combination of foreground development and designs the database part of Oracle. Component and component technology are technical means used to improve the reliability and friendliness of the website. In terms of technical maturity, there is no risk, but in order to achieve good website architecture and customer experience, compared with traditional development methods, there is a considerable amount of additional work to be done, which will bring some risks to the project duration, but the impact is small. At the same time, any website management ignoring software quality supervision will pose a huge risk to the production of the website. The quality system of the website focuses on the testing stage in development and the final maintenance stage. With the continuous expansion of the website system, it is necessary to constantly maintain and improve the website system. If the supervision is not in place, the technical support system will operate ineffective and cause losses. When analysts design the website structure, it is too customized, and the website is friendly and practical, which will bring a huge burden to later maintenance and a surge in maintenance costs. For users, there will be a significant discount on the click ratio of the website, even resulting in a sharp reduction in the number of visits. On the contrary, if the website structure is too flexible and universal, it will inevitably increase the difficulty of website development and the complexity of the website, which will bring risks in the implementation and testing stage, and the stability of the website will also be affected.

Countermeasures or measures: website builders shall communicate with users and other project team technicians to determine which development technologies are needed for the project and strengthen the learning of using corresponding technologies. Communicate with technical personnel in charge to understand their technical background and development ability. While communicating with technicians, communicate and coordinate with the company's management to ensure that new technicians can be in place on time. In the process of project development, timely record and summarize the problems, ask experts for guidance and formulate relevant countermeasures.

\section{References}

[1] Yu Zeyuan, Yin Hedong. New vision and new challenges brought by artificial intelligence [J]. Curriculum, teaching materials and teaching methods, 2019, 39 (02): 27-36.

[2] Shen Xiaobei, Luo Zhang. On the reform trend of teaching methods from the perspective of wisdom education [J]. Journal of teacher education, 2021,8 (02): 57-65.

[3] Tian Yan, He Pengyu, Du Xiaoyan. Analysis on the development path of campus media in local colleges and universities in the all media era -- Taking Shanxi Agricultural University and a secondary college as an example [J]. Chinese Journal of multimedia and network teaching (the last ten days), 2021 (06): 10-13

[4] Yin Guojun, Du Hongwen, Zhu Yuhong. Construction of a double helix model of innovation and entrepreneurship education based on the co creation of teachers and students -Taking Zhejiang University as an example [J]. Higher education research, 2019,40 (08): 77-87. 
[5] Lan Guoshuai, Guo Qian, Wei Jiacai, Yang Xiling, Yu Yameng. 5G+ Intelligent Technology: building a new ecosystem of intelligent education in the "intelligent + " era [J]. Journal of distance education, 2019,37 (03): 3-16.

[6] Jiang Jihai, Wang Fengquan. Innovation path and evolution mechanism of $\mathrm{O} 2 \mathrm{O}$ business model -- a case study of platform transformation of Pinsheng company [J]. Management review, 2017,29 (09): 249-261.

[7] Liu Xuming. Research on the process and essence of Sports Alienation in Colleges and universities in China [J]. Huazhong University of science and technology, 2019. 